\title{
STRATEGI PENINGKATAN PRESTASI BELAJAR SINTAKSIS MAHASISWA PROGRAM STUDI PENDIDIKAN BAHASA INDONESIA FKIP UNIVERSITAS BENGKULU DENGAN METODE BRAINSTORMING
}

\author{
Rokhmat Basuki ${ }^{1}$ \& Suryadi ${ }^{2}$ \\ ${ }^{1,2}$ Program Studi Pendidikan Bahasa Indonesia, FKIP, Universitas Bengkulu \\ JIn. WR. Supratman, Kelurahan Kandang Limun, Kecamatan Muara Bangka Hulu, \\ Kota Bengkulu, Kode Pos: 38371, Indonesia \\ Email: rokhmat.b58@gmail.com ${ }^{1}$,suryadi@unib.ac.id ${ }^{2}$
}

\begin{abstract}
Abstrak
Penelitian ini bertujuan mendeskripsikan proses pembelajaran sintaksis dan mengetahui peningkatan prestasi perkuliahan sintaksis dengan menggunakan metode brainstorming pada mahaiswa Program Studi Pendidikan Bahasa Indonesia FKIP Universitas Bengkulu. Metode penelitian menggunakan metode penelitian tindakan kelas. Teknik pengumpulan data menggunakan tes, wawancara, dan observasi. Subjek penelitian adalah mahasiswa semester IVc Program Studi Pendidilan Bahasa dan Sastra Indonesia, Fakultas Keguruan dan IImu Pendidikan Universitas Bengkulu. Teknik analisis data dilakukan dengan cara reduksi data, penyajian data, interpretasi hasil analisis tes, wawancara, dan observasi, serta membuat kesimpulan berdasarkan indikator keberhasilan penelitian tindakan kelas. Hasil penelitian menunjukan bahwa terjadi perubahan sikap dan perilaku mahasiswa yang lebih positif. Pada siklus pertama mahasiswa terlihat senang dan bersemangat dalam perkuliahan. Selain itu, pada siklus kedua mahasiswa semakin aktif dan antusias dalam mengikuti seluruh rangkaian perkuliahan. Prestasi perkuliahan yang diperoleh para mahasiswa dengan kategori meningkat dengan hasil memuaskan. Terbukti pada siklus pertama, nilai rata-rata mahasiswa 70 dengan rincian 7 mahasiswa yang mendapatkan nilai baik sekali atau 19\%. Mahasiswa dengan nilai baik berjumlah 19 atau 53\%. Kemudian, mahasiswa dengan nilai cukup sebanyak 10 atau $28 \%$. Sedangkan pada siklus kedua pencapaian nilai rata-rata 78,5 dengan rincian 12 mahasiswa mendapat nilai baik sekali atau $33 \%$, sedangkan mahasiswa yang mendapatkan nilai baik 24 mahasiswa atau $67 \%$.
\end{abstract}

Kata kunci: strategi pembelajaran, pembelajaran sintaksis, metode brainstorming

\section{STRATEGIES FOR IMPROVING STUDENT SYNTAX LEARNING ACHIEVEMENT IN THE STUDY PROGRAM OF INDONESIAN LANGUAGE EDUCATION FKIP BENGKULU UNIVERSITY WITH BRAINSTORMING METHOD}

\begin{abstract}
This study aims to describe the syntactic learning process and find out the improvement of syntactic lecture achievement by using the brainstorming method in the students of the Indonesian Language Study Program at FKIP Bengkulu University. The research method uses classroom action research methods. Data collection techniques using tests, interviews, and observations. The research subjects were students in the IVC semester of the Indonesian
\end{abstract}


Language and Literature Education Study Program, Faculty of Teacher Training and Education, Bengkulu University. Data analysis techniques were carried out utilizing data reduction, data presentation, interpretation of test analysis results, interviews, and observations, and making conclusions based on indicators of success in classroom action research. The results showed that there were changes in students' attitudes and behaviors that were more positive. In the first cycle, students look happy and excited in lectures. Besides, in the second cycle, students were increasingly active and enthusiastic in participating in the whole series of lectures. Lecture achievements obtained by students in the category increased with satisfying results. Proven in the first cycle, the average value of 70 students with details of 7 students who get excellent grades or $19 \%$. Students with good grades are 19 or $53 \%$. Then, students with sufficient grades of 10 or $28 \%$. Whereas in the second cycle the achievement of an average score of 78.5 with the details of 12 students got excellent grades or $33 \%$, while students who got good grades were 24 students or $67 \%$.

Keywords: learning strategies, syntactic learning, brainstorming methods

\section{A. Pendahuluan}

Keberhasilan tujuan perkuliahan ditentukan oleh banyak faktor di antaranya faktor dosen dalam melaksanakan proses perkuliahan, karena dosen secara langsung dapat mempengaruhi, membina dan meningkatkan kecerdasan serta keterampilan mahasiswa. Hal ini sesuai dengan pendapat Noermanzah (2015:274) dan Noermanzah \& Friantary (2019:6631) bahwa peran dosen bahasa Indonesia harus mampu memfasilitasi mahasiswa untuk bisa kreatif, berpikir kritis, kolaboratif, dan bekerja sama. Untuk itu, diharapkan dosen memiliki cara atau model mengajar yang baik dan mampu memilih model perkuliahan yang tepat dan sesuai dengan konsep-konsep mata kuliah yang akan disampaikan.

Pada hakikatnya kegiatan perkuliahan di perguruan tinggi adalah suatu proses interaksi atau hubungan timbal balik antara dosen dengan mahasiswa dalam satuan pembelajaran. Dosen sebagai salah satu komponen dalam proses belajar mengajar tersebut merupakan pemegang peran yang sangat penting. Dosen bukan sekedar penyampai materi, tetapi lebih dari itu dosen dapat dikatakan juga sebagai sentral pembelajaran.

Sebagai pengatur sekaligus pelaku dalam proses perkuliahan, dosen harus dapat mengarahkan bagaimana proses perkuliahan itu dilaksanakan. Oleh karena itu, dosen harus dapat menciptakan suatu perkuliahan yang efektif dan menarik sehingga materi perkuliahan yang disampaikan membuat mahasiswa tertarik dan merasa perlu untuk mempelajari bahan perkuliahan tersebut. 
Dosen juga mengemban tugas yang berat untuk tercapainya tujuan pendidikan nasional yaitu meningkatkan kualitas manusia Indonesia, manusia seutuhnya yang beriman dan bertakwa kepada Tuhan Yang Maha Esa, berbudi pekerti luhur, berkepribadian, disiplin, bekerja keras, tangguh, bertanggung jawab, mandiri, cerdas, dan terampil, serta sehat jasmani dan rohani. Kemudian, harus mampu menumbuhkan dan memperdalam rasa cinta terhadap tanah air, mempertebal semangat kebangsaan dan rasa kesetiakawanan sosial. Sejalan dengan itu pendidikan nasional akan mampu mewujudkan manusia-manusia pembangunan dan membangun dirinya sendiri serta bertanggung jawab atas pembangunan bangsa (Depdikbud, 1999). Untuk itu, diperlukan suatu upaya dalam rangka meningkatkan mutu pendidikan dan pengajaran kebahasaan, salah satunya adalah dengan memilih strategi atau cara dalam menyampaikan materi perkuliahan agar diperoleh peningkatan prestasi belajar mahasiswa, khususnya pada Matakuliah Sintaksis.

Berdasarkan pengamatan yang peneliti lakukan terhadap mahasiswa Program Studi Pendidikan Bahasa Indonesia FKIP Universitas Bengkulu saat ujian komprehensif. Mereka ketika diberi pertanyaan oleh dosen penguji tentang aspek kebahasaan, lebih khusus sintaksis, mahasiswa banyak yang mengalami kesulitan untuk menjawab atau menjelaskan. Ironisnya, mereka seolah-olah lupa seakan-akan belum pernah belajar atau mendapatkan materi itu. Hal ini bisa disebabkan karena dosen selama ini dalam proses belajar mengajar hanya menggunakan metode ceramah, diskusi, dan atau hanya menggunakan alat peraga yang ada, dan kurang variatif.

Alternatif strategi, teknik, dan cara pembelajaran sintaksis yang ditawarkan untuk meningkatkan pemahaman mahasiswa terhadap konsep sintaksis tersebut adalah dengan metode curah pendapat (brainstorming). Dengan demikian, diharapkan akan menguatkan pemahaman mahasiswa terhadap konsep-konsep sintaksis yang diajarkan. Pemahaman itu memerlukan minat dan motivasi. Tanpa adanya minat, menandakan bahwa mahasiswa tidak mempunyai motivasi untuk belajar. Pengertian metode curah pendapat (brainstorming) adalah suatu teknik kreativitas, yang mengupayakan pencarian penyelesaian dari suatu masalah tertentu dengan mengumpulkan gagasan secara spontan dari anggota kelompok 
(Firdaus, dkk. 2019 \& Amin, 2017). Istilah brainstorming ini dipopulerkan oleh Alex F. Osborn yang menjelaskan bahwa brainstorming merupakan cara-cara yang ditempuh guru untuk berpikir secara lateral, membantu mahasiswa untuk keluar dari pola pikir rutin, yaitu dengan melontarkan suatu masalah ke para mahasiswa, kemudian mahasiswa menjawab atau menyatakan pendapat atau berkomentar sehingga masalah tersebut berkembang menjadi masalah baru, atau dapat diartikan pula sebagai suatu cara untuk mendapatkan banyak ide dari sekelompok manusia dalam waktu singkat (Roestiyah, 2001:73 \& Rawlinson, 2017:35-36). Tujuan dari metode ini adalah melatih pikiran siswa untuk merumuskan pendapatnya dengan bahasa dan kalimat yang baik sehingga perbendaharaan kata dan kemampuan berpikir seseorang bisa dilatih dan ditingkatkan (Indihadi, 2018).

Hasil penelitian relevan menunjukkan bahwa metode brainstorming mampu meningkatkan kemampuan menulis persuasif siswa (Firdaus, dkk., 2019) dan mampu meningkatkan kemampuan berpikir kritis siswa (Utami, 2015). Dari penelitian ini menunjukkan bahwa metode brainstorming terbukti mampu memotivasi siswa dalam belajar khususnya dalam menulis dan kemampuan berpikir kritis. Diharapkan juga metode brainstorming ini mampu meningkatkan kemampuan mahasiswa dalam penguasaan pada Matakuliah Sintaksis. Sintaksis merupakan salah satu cabang ilmu lingustik yang membahas unsur internal kalimat yaitu, frase, klausa, dan kalimat (Sudaryanto, 2015 \& Noermanzah, 2017).

Dalam pembelajaran kebahasaan, khususnya sintaksis, dosen dapat melakukan simulasi perkuliahan dengan menggunakan umpan pertanyaan. Umpan pertanyaan itu bisa berupa topik frase atau kalimat. Umpan pertanyaan tersebut tidak hanya menjadikan mahasiswa terlibat dalam perkuliahan sintaksis yang bergairah, juga dapat menentukan seberapa jauh mahasiswa menanggapi pertanyaan tersebut dari suatu kegiatan pembelajaran atau seberapa jauh menyerap informasi yang disajikan sehingga menghasilkan penguasaan materi yang optimal bagi mahasiswa.

Strategi yang dibuat menyangkut masalah cara mempelajari frase, klausa dan kalimat, baik secara fungsi, kategori dan peran dalam bahasa. Pembicaraan 
tentang subjek, predikat, objek, pelengkap, dan keterangan, biasanya terletak pada tataran kalimat sebagai unsur kalimat. Fungsi unsur klausa ditentukan berdasarkan ciri formal, ialah bedasarkan intonasi dan perilaku unsur-unsur itu dalam suatu klausa (Ramlan, 1987:xviii). Lebih lanjut, Ramlan (1987:17), menyatakan bahwa sintaksis merupakan bagian atau cabang dari ilmu bahasa yang membicarakan seluk beluk wacana, kalimat, klausa, dan frase.

Berdasarkan latar belakang di atas, maka permasalahan dalam penelitian ini dapat dirumuskan sebagai berikut: (1) Bagaimanakah perencanaan pembelajaran Matakuliah Sintaksis dengan menggunakan metode brainstorming, (2) Bagaimanakah peningkatan prestasi belajar mahasiswa Program Studi Pendidikan Bahasa Indonesia FKIP Universitas Bengkulu Tahun Ajaran 2018/2019 dengan diterapkannya metode brainstorming dalam pembelajaran Matakuliah Sintaksis?

\section{B. Metode Penelitian}

Metode penelitian yang digunakan adalah penelitian tindakan kelas. Rancangan tindakan yang dilakukan melalui dua siklus. Masing-masing siklus terdiri dari 4 tahap, yaitu tahap-tahap penelitian meliputi perencanaan (planning), pelaksanaan tindakan (action), pengamatan (observasion), dan refleksi (reflection). Data penelitian ini menggunakan dua macam data, yaitu data kualitatif dan data kuantitatif. Instrumen penelitian adalah peneliti yang dibantu dosen sejawat. Pengumpulan data menggunakan tes, wawancara, dan observasi yang dilakukan oleh peneliti dibantu dosen sejawat. Analisis data yang digunakan adalah teknik analisis interaktif, yang dimulai dari pengumpulan data, reduksi data, penyajian data, dan penyimpulan. Informasi yang diperoleh dalam pengumpulan data pada perkuliahan Sintaksis dengan penggunaan metode brainstorming ini diperoleh dari analisis terhadap hasil post test, wawancara, dan catatan observasi. Kemudian, untuk keabsahan data dalam penelitian ini dilakukan trianggulasi sumber data, yaitu membandingkan antara hasil tes, wawancara, dan observasi.

Pada penelitian ini, peneliti sekaligus sebagai dosen melakukan: menyusun angket untuk pembelajaran dan menyusun rencana program pembelajaran. Adapun prinsip-prinsip penelitian tindakan tersebut terbagi atas tahap 
perencanaan, pelaksanaan, observasi serta refleksi. Ketiga tahap tersebut dilaksanakan dengan model siklus: (1) tahap diagnostik, yaitu hasil yang diharapkan dari tahap ini adalah inventarisasi kendala dan kesulitan yang dialami mahasiswa Prodi Pendidikan Bahasa Indonesia Fakultas Keguruan dan IImu Pendidikan Universitas Bengkulu, dalam belajar sintaksis, yang harus berusaha memperoleh kesempatan atau event guna untuk mengingat seluk-beluk sintaksis. Berdasarkan gambaran di atas, maka hipotesis tindakan dapat dirumuskan sebagai berikut: "Dengan diterapkannya strategi pembelajaran mata kuliah Sintaksis dengan menggunakan metode brainstorming, kualitas perkuliahan mata kuliah Sintaksis mahasiswa prodi Pendidikan Bahasa Indonesia FKIP Unib. (2) Tahap terapeutik, yakni: Berdasarkan hasil klarifikasi dan diskusi antara peneliti, yang sekaligus sebagai dosen pengampu mata kuliah Sintaksis, dengan dosen mitra pengampu mata kuliah Sintaksis ini, maka pada tahap selanjutnya, hasil yang diharapkan adalah mahasiswa mampu memahami berbagai seluk-beluk sintaksis, termasuk memahami karakteristik kebahasaan Sintaksis dengan menggunakan metode brainstorming. Langkah ini dimaksudkan agar tumbuhkembang skills mahasiswa dalam pembelajaran sintaksis. Untuk itu, pelaksanaan perancangan dan penyusunan tahap-tahap pembelajaran mata kuliah Sintaksis itu dilakukan bersama-sama dengan mahasiswa dan dimonitor dengan seksama oleh peneliti dan dosen mitra.

(3) Tahap diagnostik ulang atau refleksi, yakni: berdasarkan hasil pengamatan dan refleksi, diharapkan pada tahap ini secara bersama-sama dosen dapat mengevaluasi hasil perbaikan dari tahap terapeutik, mengingat tahap sebelumnya dimungkinkan mahasiswa masih banyak mengalami kesulitan dalam menerapkan metode brainstorming ini. Kemudian, berdasar hasil perbaikan evaluasi itu, maka hipotesis tindakan perlu diverifikasi, dan masalah yang belum terselesaikan dispesifikasi dan diteliti kembali penyebabnya. Setelah itu hipotesis tindakan perlu dirumuskan kembali berdasarkan hasil diagnostik ulang tersebut, dan. 4) Tahap terapi ulang, yakni: berdasarkan hasil diagnostik ulang atau refleksi di atas, maka pada tahap ini hasil yang diharapkan dosen dan mahasiswa secara bersama-sama dapat merancang perbaikan ulang, yaitu perancangan dan 
penyusunan tahap (fase) perkuliahan Sintaksis dengan metode brainstorming. Perbaikan ulang perlu dimonitor lagi secara seksama oleh peneliti dan dosen mitra; (5) dan seterusnya.

Siklus tindakan diulang lagi sampai ditemukan strategi pembelajaran sintaksis dengan lebih baik, dan kemampuan dosen dalam merancang, menyusun dan melakukan tahap-tahap pembelajarannya dengan strategi pembelajaran yang menggunakan metode brainstorming. Ditegaskan oleh Kemmis \& Mc.Taggart (1988), bahwa siklus pertama proses penelitian tindakan diawali dengan identifikasi awal, pencarian fakta, dan analisis untuk menemukan masalah umum penelitian, dilanjutkan dengan pelaksanaan tindakan, observasi, dan refleksi (perenungan, pemikiran, dan evaluasi). Siklus kedua dilakukan perbaikan masalah umum dengan perencanaan lebih terfokus, dilanjutkan dengan pelaksanaan tindakan, observasi, dan refleksi. Pada siklus ketiga, siklus keempat berdasarkan hasil refleksi ditentukan perumusan masalah secara terfokus dengan perencanaan tindakan yang terfokus pula, dilanjutkan dengan pelaksanaan penelitian, observasi dan refleksi. Hasil refleksi pada akhirnya diorientasikan pada kemungkinan dampak praktis untuk pembelajaran di kelas.

Secara sederhana, penelitian ini akan mengacu pada konsep penelitian tindakan kelas sebagaimana dilakukan oleh Suyatno (2009:120). Adapun konsep tindakan dalam penelitian ini yaitu sebagai berikut: (1) Wawancara awal dilakukan pada dosen dan mahasiswa untuk menentukan tindakan. Wawancara dilakukan untuk mengetahui kondisi awal mahasiswa. (2) Angket merupakan data penunjang yang digunakan untuk mengumpulkan informasi terkait dengan respon atau tanggapan mahasiswa terhadap penerapan pembelajaran kooperatif. (3) Observasi dilaksanakan untuk memperoleh data kemampuan berpikir siswa yang terdiri dari beberapa deskriptor yang ada selama pembelajaran berlangsung. Observasi ini dilakukan dengan menggunakan lembar observasi yang telah disusun. Obsevasi dilakukan oleh 2 orang observer: (1) tes dilaksanakan setiap akhir siklus, hal ini dimaksudkan untuk mengukur hasil yang diperoleh siswa setelah pemberian tindakan. Test tersebut berbentuk multiple choise agar banyak materi tercakup; (2) catatan lapangan digunakan sebagai pelengkap data 
penelitian sehingga diharapkan semua data yang tidak termasuk dalam observasi dapat dikumpulkan pada penelitian ini.

Penelitian ini akan dilaksanakan dalam 2 siklus. Setiap siklus tediri dari perencanaan, tindakan, penerapan tindakan, observasi, refleksi. (1) Sebelum melaksanakan tindakan maka perlu dilakukan persiapan. Kegiatan pada tahap ini meliputi: (a) penyusunan RPS dengan model pembelajaran yang direncanakan dalam PTK; (b) penyusunan lembar masalah/lembar kerja mahasiswa sesuai dengan indikator perkuliahan yang ingin dicapai; (c) membuat soal test yang akan diadakan untuk mengetahui hasil pembelajaran sintaksis mahasiswa; (d) pembentuk kelompok yang bersifat heterogen, baik dari segi kemampuan akademis, jenis kelamin, maupun etnis; (e) memberikan penjelasan kepada mahasiswa mengenai teknik pelaksanaan model pembelajaran yang akan dilaksanakan. (2) Pelaksanaan tindakan: (a) melaksanakan kegiatan sesuai dengan rencana pembelajaran yang telah dibuat. Dalam pelaksanaan penelitian dosen menjadi fasilitator selama pembelajaran, dan mahasiswa dibimbing untuk belajar sintaksis dengan menggunakan metode brainstorming. Adapun langkahlangkah yang dilakukan adalah menyesuaikan dengan skenario pembelajaran, (b) Kegiatan penutup. Di akhir pelaksanaan pembelajaran pada tiap siklus, dosen memberikan test secara tertulis untuk mengevaluasi hasil perkuliahan sintaksis mahasiswa, selama proses pembelajaran berlangsung. (1) Pengamatan dilakukan selama proses pembelajaran berlangsung dengan melakukan kolaborasi dalam pelaksanaannya. (2) Pada tahap ini dilakukan analisis data. Hasil analisis data yang telah ada dipergunakan untuk melakukan evaluasi terhadap proses dan hasil yang ingin dicapai.Refleksi dimaksudkan sebagai upaya untuk mengkaji apa yang telah atau belum terjadi, apa yang dihasilkan, mengapa hal itu terjadi dan apa yang perlu dilakukan selanjutnya.

Hasil refleksi digunakan untuk menetapkan langkah selanjutnya dalam upaya untuk menghasilkan perbaikan pada siklus II. Kegiatan siklus II pada dasarnya sama dengan siklus I, hanya saja perencanaan kegiatannya didasarkan pada hasil refleksi siklus I sehingga lebih mengarahkan pada perbaikan pelaksanaan siklus I.Kualitas pembelajaran sintaksis mahasiswa dianalisis dengan rubrik. 
Kemudian untuk mengetahui peningkatan skor kemampuan berpikir, pertanyaan dan jawaban yang telah dinilai dengan rubrik pada siklus I dibandingkan dengan pertanyaan dan jawaban yang telah dinilai dengan rubrik pada siklus II.

Rumus untuk mencari skor klasikal kemampuan belajar sintaksis mahasiswa Skor riil X 4 Skor maksimal

Keterangan:

Skor riil : : skor total yang diperoleh mahasiswa

Skor maksimal: Skor total yang seharusnya diperoleh mahasiswa

Angka 4 : Skor maksimal dari tiap jawaban

Hasil belajar pada aspek kognitif dari hasil test dianalisis dengan teknik analisis evaluasi untuk mengetahui ketuntasan belajar mahasiswa.Caranya adalah dengan menganalisis hasil test formatif dengan menggunakan kriteria ketuntasan belajar. Secara individu, mahasiswa dianggap telah belajar tuntas apabila daya serapnya mencapai $65 \%$. Secara kelompok dianggap tuntas jika telah mencapai 85\% dari jumlah mahasiswa yang mencapai daya serap minimal 65\% (Depdikbud, 1999). Diharapkan dengan strategi pembelajaran dalam mata kuliah sintaksis dengan menggunakan metode brainstorming, maka prestasi hasil belajar mahasiswa Program Studi Pendidikan Bahasa Indonesia FKIP Universitas Bengkulu dapat meningkat.

\section{Hasil Penelitian dan Pembahasan}

\section{Hasil Penelitian}

Hasil penelitian yang diperoleh dari data wawancara, observasi dan tes terhadap penerapan metode brainstorming pada pembelajaran sintaksis Mahasiswa Program Studi Pendidikan Bahasa Indonesia FKIP Universitas Bengkulu dapat diinformasikan bahwa: (1) hasil belajar sintaksisi dengan metode brainstorming ini diikuti dengan perubahan sikap dan perilaku mahasiswa yang lebih positif. Pada siklus I mahasiswa terlihat senang dan bersemangat dalam pembelajaran. Selain itu, mahasiswa semakin aktif dan antusias dalam mengikuti seluruh rangkaian pembelajaran. (2) Hasil perkuliahan sintaksis meningkat dengan hasil memuaskan. Terbukti pada siklus pertama, nilai rata-rata mahasiswa 70 (tujuh puluh) dengan rincian 7 (tujuh) mahasiswa nilai baik sekali atau $19 \%$. 
Mahasiswa dengan nilai baik 19 (sembilan belas) atau $53 \%$, dan mahasiswa dengan nilai cukup 10 (sepuluh) atau 28\%. Kemudian, pada siklus kedua pencapaian nilai rata-rata 78,5 (tujuh puluh delapan koma lima) dengan rincian 12 (dua belas) mahasiswa mendapat nilai baik sekali atau $33 \%$, sedangkan mahasiswa yang mendapatkan nilai baik 24 (dua puluh empat) mahasiswa atau $67 \%$.

\section{Pembahasan}

Penelitian tindakan kelas yang dilakukan menunjukkan bahwa strategi peningkatan prestasi belajar sintaksis mahasiswa Program Studi Pendidikan Bahasa Indonesia FKIP Universitas Bengkulu dengan metode brainstorming mampu meningkatkan motivasi siswa untuk belajar dan mampu meningkatkan kemampuan mahasiswa dalam memahami konsep sintaksis. Hal ini menunjukkan bahwa metode brainstorming mampu meningkatkan kemampuan berpikir kritis siswa ketika belajar sehingga mampu menuangkan gagasannya dalam tugas menulis tentang konsep sintaksis. Hal ini sesuai dengan hasil penelitian sebelumnya yang sudah dilakukan oleh Firdaus, dkk., (2019) dan Utami (2015) bahwa metode brainstorming mampu meningkatkan kemampuan berpikir kritis dan kemampuan menulis peserta didik.

Penelitian ini terdiri atas 2 siklus. Pada siklus pertama tersebut, seluruh mahasiswa Semester IV kelas C hadir. Awal tindakan pembelajaran dosen mengawali dengan menyampaikan instrumen pertanyaan materi sintaksis yang dianggap paling sulit dihafal dan dipahami oleh mahasiswa. Hasilnya menunjukkan bahwa rata-rata mahasiswa semester IV C kebingungan dalam menentukan kalimat yang berhubungan dalam bentuk dan artinya. Oleh karena itu, penelitian ini dilakukan dengan maksud agar mahasiswa Program Studi Pendidikan Bahasa Indonesia dapat mempunyai teknik memahami dan mengerti sintaksis dalam Bahasa Indonesia, apakah kalimat itu terdiri dari satu kata atau beberapa kata. Dengan demikian, mahasiswa memiliki bekal meningkatkan kemampuan pembelajaran aspek sintaksis di masa mendatang setelah mereka menjadi guru. Sebelum penelitian tindakan kelas ini dilaksanakan, terlebih dahulu peneliti dan dosen mitra pada Matakuliah Sintaksis Bahasa Indonesia menyusun 
rencana tindakan secara baik, seperti materi pembelajaran, skenario pembelajaran, dan instrumen pertanyaan yang akan diperlukan dalam pelaksanaan tindakan.

Pra penelitian diawali pada pertemuan pertama, yakni di GKB IV ruang 17 pada semester IV kelas C. Setelah memberi salam dan mengecek kehadiran mahasiswa, dosen peneliti yang didampingi dosen mitra dan teman sejawat melakukan penjajakan terhadap penguasaan materi Sintaksis Bahasa Indonesia mahasiswa tentang defenisi dan pengertian sintaksis, frasa, dan seluk-beluk kalimat yang mereka ketahui. Ternyata cukup banyak mahasiswa yang menyatakan lupa, tidak tahu, bahkan ada yang menyatakan baru mendengar istilah-istilah tersebut. Tentu saja keadaan ini cukup mengkhawatirkan sehingga agar memperoleh data yang akurat dosen melakukan tes awal yang berkaitan dengan materi Sintaksis Bahasa Indonesia tersebut. Dalam hal ini mahasiswa diminta untuk menjawab pertanyaan yang telah dipersiapkan dosen. Cukup 'gaduh' suasana ruang kelas pada waktu itu, karena mahasiswa tidak menyangka sama sekali mereka akan mendapatkan pertanyaan seperti itu. Setelah cukup waktu dosen, kemudian meminta mahasiswa mengumpulkan lembar observasi yang telah diisi itu ke depan kelas. Maka dilakukan penilaian. Adapun hasilnya, sangat memprihatinkan. Rata-rata jawaban mahasiswa masih belum sempurna atau belum lengkap. Dalam hal ini dosen memberikan penguatan bahwa mahasiswa-mahasiswa tersebut harus memiliki pengetahuan untuk 'menandai' berbagai aspek sintaksis, karena hal itu dapat membantu pemahamaan mahasiswa daripada sekedar mengucapkan banyak kata. Apalagi setelah mereka selesai studi dari program studi ini, nantinya akan menjadi guru bahasa Indonesia, yang harus membekali diri dengan banyak menguasai berbagai pengertian tentang sintaksis.

Pelaksanaan tindakan siklus I, (1) dosen mengecek daftar hadir mahasiswa, (2) dosen memberikan apersepsi kepada mahasiswa untuk menarik perhatian mereka terhadap materi pembelajaran yang akan disampaikan, (3) mahasiswa menyimak materi pembelajaran tentang "frase" dan "seluk-beluknya" dalam bahasa Indonesia,(3) dosen menjelaskan salah satu teknik mengenal dan mengerti secara lebih cepat tentang kedua materi di atas kepada mahasiswa. 
Adapun teknik yang dijelaskan adalah model brainstorming alat bantu berupa pancingan pertanyaan yang dapat digunakan mahasiswa mengingat dan mempelajari informasi yang baru diterimanya, (4) mahasiswa terlihat cukup antusias mendengarkan pertanyaan penjelasan dosen tentang itu, karena mahasiswa sebelumnya merasa terlalu sulit membedakan dan menghafal materimateri sintaksis tersebut. Menurut para mahasiswa, materi tersebut seperti kebebasan berpikir, sehingga apabila dipahami satu, maka harapan mereka yang lain dapat dipahami. Dalam hal ini dosen memberikan penguatan bahwa mahasiswa-mahasiswa tersebut saat menjadi guru bahasa Indonesia telah menguasai dan membekali diri dengan teknik yang sederhana, (5) setelah dinilai mahasiswa paham tentang metode di atas, maka dosen meminta kepada mahasiswa untuk memulai mengemukakan pendapat yang telah dibuat dan ditulisi materi "frase" sesuai kesepakatan di atas. Dosen menunjukkan prosedur curah gagasan untuk digunakan dalam belajar sintaksis kepada mahasiswa, yaitu: (1) membaca materi "frase" secara lengkap; (2) perhatikan inti yang harus dipelajari. Dosen memberi waktu kepada mahasiswa untuk membaca dan kemudian menguraikannya sesuatu yang telah dipersiapkan atas masing-masing materi yang telah ditentukan di atas dengan menggunakan model curah gagasan. Mahasiswa diharapkan bisa tuntas membuat membahas tema tersebut.

Pada saat dilakukan kegiatan itu tampak perilaku dan sikap mahasiswa yang bermacam-macam. Ada yang serius, ada yang menengok-nengok temannya kiri kanan, ada juga yang menunjukkan ekspresi kebingungan meski awalnya ragu untuk mengungkapkan gagasan yang sudah dikuasainya. Selanjutnya, setelah waktu yang sudah ditentukan berllu, mahasiswa diminta untuk membaca ulang materi yang telah dipelajari diungkap kembali agar tidak ada yang salah pengertian. Selanjutnya, mahasiswa harus menyimpulkan bersama dengan dosen, apa-apa yang sudah dibicarakannya (6) Selanjutnya, dosen menguraikan secara sekilas kepada tiap mahasiswa, dan mahasiswa-mahasiswa tersebut harus menyebutkan kembali apa-apa yang sudah disimpulkannya.

Setelah pelaksanaan siklus I selesai, peneliti, dan teman sejawat, bertemu untuk melakukan refleksi terhadap kegiatan perkuliahan Sintaksis Bahasa 
Indonesia yang telah berlangsung. Refleksi dilakukan dengan melihat hasil catatan observasi dari peneliti dengan dosen mitra, maupun catatan dari teman sejawat, serta didasarkan diskusi hasil tindakan yang telah dilakukan pada siklus I, maka tergambarkan hasilnya.

Dari catatan dan diskusi itu terungkap beberapa hal yang masih menjadi kelemahan dari pelaksanaan Brainstorming ini, di samping juga terungkap berbagai keunggulan dan keberhasilan dari pelaksanaan pembelajaran sintaksis khusus pada materi "frase" dan "seluk-beluknya" dalam Bahasa Indonesia dengan motode brainstorming. Beberapa catatan dan masukan itu dapat disampaikan berikut ini: (1) masih muncul keraguan dan rasa tidak percaya diri dari mahasiswa bahwa mereka dapat cepat memahami materi di atas dalam waktu yang lebih singkat; (2) mahasiswa yang kurang proaktif dalam mengikuti perkuliahan ini cenderung mengalami kesulitan mengembangkan brainstorming atas dua materi yang telah disepakati di atas, meskipun sederhana, tetapi harus dicermati secara sistematis, tidak boleh seenaknya. Dengan demikian, hasil maksimal metode Brainstorming ini akan dapat kita rasakan. (3) Dosen tampak sedikit kewalahan dalam mendampingi dan juga memotivasi mahasiswa karena belum adanya pengalaman dan gambaran hasil perkuliahan yang menggunakan metode brainstorming. Mahasiswa saling berebut minta perhatian dosen atas kesempatan mereka, sehingga dosen pada saat mengatur ritme tersebut belum maksimal. Perlu disempurnakan lagi sehingga hasilnya dapat lebih baik. (4) Dalam mengajukan masalah atau pengetahuan kepada mahasiswa, dosen terlihat belum sepenuhnya siap karena ungkapan atau tuturan yang kemukakan oleh mahasiswa masih sangat polos dan sederhana. (5) Masih belum sempurnanya teknik dan bahan perkuliahan yang dipersiapkan dosen secara khusus. Kemudian, (6) perlu diupayakan lagi perilaku kreatif, baik dari dosen pengampu matakuliah maupun mahasiswa yang mengambil Matakuliah Sintaksis Bahasa Indonesia.

Dalam penelitian siklus I diperoleh hasil belajar Sintaksis Bahasa Indonesia dengan metode brainstorming, mahasiswa terbukti pada siklus pertama, nilai ratarata mahasiswa 70 (tujuh puluh) dengan rincian 7 (tujuh) mahasiswa nilai baik sekali atau $19 \%$. Mahasiswa dengan nilai baik 19 (sembilan belas) atau $53 \%$. Dan mahasiswa dengan nilai cukup 10 (sepuluh) atau 28\%. Hasil perkuliahan 
sintaksis bahasa Indonesia dengan metode brainstorming ini diikuti dengan perubahan sikap dan perilaku mahasiswa yang lebih positif. Pada siklus I mahasiswa terlihat kurang senang dan kurang bersemangat dalam pembelajaran. Selain itu, mahasiswa semakin aktif dan antusias dalam mengikuti seluruh rangkaian pembelajaran. Dari hasil penelitian tentang pembelajaran bahasa bidang Sintaksis Bahasa Indonesia dengan metode brainstorming, mahasiswa di atas, dapat disimpulkan bahwa kemampuan mahasiswa dalam memahami frase, dan mengenal jenis-jenis frase, klausa dan kalimat dalam Bahasa Indonesia mengalami peningkatan setelah mengikuti proses pembelajaran dengan brainstorming ini, dan perilaku mahasiswa mengalami perubahan lebih terbuka dan lebih antusias belajar tentang aspek kebahasaan, sekaligus menjadi lebih positif. Pelaksanaan tindakan siklus 2.

Sebelum penelitian tindakan kelas Siklus II dilakukan, dosen menanyakan kepada mahasiswa apakah merasa terbantu dalam memahami materi-materi kebahasaan, khususnya aspek sintaksis apabila menggunakan pembelajaran dengan brainstorming sebagaimana yang minggu lalu telah ditugaskan dosen.Jawaban mahasiswa cukup positif, karena menurut penjelasan mereka metode itu dapat membantu belajar mengingat suatu materi secara lebih fokus dan timbul rasa empati atas satu materi. Tentu saja pernyataan mahasiswa tersebut menjadi modal dan motivasi bagi mereka sendiri untuk dapat melaksanakan siklus ke-2 ini dengan lebih serius dan cermat. Mahasiswa Program Studi Pendidikan Bahasa dan Sastra Indonesia, Jurusan Pendidikan Bahasa dan Seni, FKIP Universitas Bengkulu, yang menjadi subyek penelitian tindakan kelas ini berjumlah 36 orang, terdiri atas 31 perempuan dan 5 laki-laki tersebut dibagi menjadi 2 (dua) kelompok. Setelah siap semua, kemudian dilaksanakan tindakan kelas, berupa (1) Dosen mengecek daftar hadir mahasiswa. Kemudian dosen memberi apersepsi kepada mahasiswa dan mengulang kembali materi yang pernah disampaikan pada pertemuan minggu sebelumnya yakni tentang frase, klausa dan kalimat. (2) Dosen kemudian mengajak mahasiswa menyepakati materi kedua untuk disampaikan dalam tindakan siklus kedua ini. Topik yang disepakati oleh mahasiswa karena dianggap 
dapat membingungkan adalah masalah frase, klausa, dan kalimat. Oleh karena itu, tentang materi tersebut dituangkan ke dalam bentuk pertanyaan yang ditujukan pada masing-masing mahasiswa. (3)Dosen menjelaskan kepada mahasiswa tentang frase, klausa dan kalimat dalam bahasa Indonesia dan mahasiswa menanggapi dengan model curah gagasan. (4) Mahasiswa semakin memahami pendapat masing-masing mahasiswa tentang, seluk-beluk frase, klausa dan kalimat. Mereka terlihat lebih serius dan antusias. Berbeda dengan kondisi pada waktu tindakan siklus I, pada tindakan ini mereka terlihat sudah dapat berkonsentrasi dalam menanggapi pertanyaan-pertanyaan dosen, mereka tidak terlihat lagi wajah-wajah kebingungan dari mahasiswa, meskipun waktu yang diberikan untuk menyelesaikan permasalahan itu juga dibatasi. Dalam hal ini dosen memberikan penguatan bahwa pemikiran tentang materi tersebut dapat dikembangkan untuk bidang-bidang yang lain. (5) Pada kegiatan akhir, mahasiswa bersama-sama dengan dosen mengulas kembali bagaimana memberikan curah gagasan dengan harapan bahwa metode ini dapat membantu mahasiswa lebih memperkaya dan menambah wawasan pemahaman materi lainnya, sehingga menjadi bekal mereka terutama setelah menjadi guru nanti. Kemudian, (6) Setelah waktu perkuliahan 120 menit berlalu, maka dosen mengakhiri kegiatan dengan mengucapkan salam dan meninggalkan ruang kelas.

Setelah pelaksanaan tindakan siklus ke-2 berakhir sesuai dengan rencana, dosen peneliti dan dosen mitra bertemu untuk melakukan refleksi terhadap kegiatan belajar mengajar yang telah berlangsung. Berdasarkan pengamatan yang dilakukan, ternyata yang menjadi kekurangan dan kelemahan yang terdapat pada tindakan siklus I sudah dapat diperbaiki dan dioptimalkan tindakannya sehingga memungkinkan tindakan siklus II berjalan dengan lebih baik dengan hasil yang lebih meningkat pula, seperti: 1) suasana kelas menjadi lebih kondusif, mahasiswa tidak lagi merasa minder atau bingung harus menyelesaikan satu per satu materi sintaksis yang mereka buat dalam tempo atau waktu lebih singkat. Masing-masing mampu berkonsentrasi dengan pemikirannya. (2) Mahasiswa memiliki antusias dan minat yang tinggi untuk mempelajari materi sintaksis lainnya dengan menggunakan metode brainstoming. Mereka menyadari apabila teknik belajar kebahasaan dilakukan secara variatif, inovatif, gembira, dan sederhana, 
maka hasil pembelajarannya akan lebih baik, tidak membosankan atau jenuh. Bahkan belajar bahasa Indonesia menjadi pelajaran favorit. Kemudian, (3) dosen pun sangat mengapresiasi hasil yang dilakukan mahasiswa untuk mengembangkan teknik belajar sintaksis dengan metode brainstorming, meskipun tidak lagi dilaksanakan di ruangan kelas. Keinginan untuk menambah wawasan berpikir untuk berbagai mata kuliah yang lain menjadi motivasi mereka yang selama ini tidak dipikirkan oleh mereka. Ternyata teknik brainstorming, dapat menjadi salah satu model belajar dengan cepat, efektif, tetapi tidak membosankan. Dengan demikian, tidak ada lagi keluhan yang menyatakan keberatan atau kewalahan mempelajari bidang linguistik atau kebahasaan sebagaimana selama ini.

Berdasarkan hasil pada tindakan siklus ke-2 di atas, maka setelah terjadi kesepakatan antara dosen peneliti dengan dosen mitra, maka pada siklus ke-2 ini hanya menggunakan 1 (satu) topik pembahasan, untuk melihat apakah terjadi perbedaan hasil ketuntasan belajar sintaksis bahasa Indonesia, menjadi lebih baik atau justru menurun dibanding hasil pada tindakan siklus I. Dalam pertemuan siklus ke-2 ini, mahasiswa yang hadir berjumlah 36 orang, terdiri dari 31 orang perempuan dan 5 orang laki-laki menghasilkan: Pada siklus ke-2 ini dihasilkan $100 \%$ atau 36 siswa dikategorikan tuntas, sedangkan nilai rata-rata klasikal mencapai 78,5. Dengan demikian, terjadi peningkatan kategori dari siklus I ke siklus II. Peningkatan hasil perkuliahan sintaksis Bahasa Indonesia dengan teknik brainstorming ini juga diikuti dengan perubahan sikap dan perilaku mahasiswa yang lebih positif. Pada siklus II mahasiswa terlihat senang dan bersemangat dalam pembelajaran. Selain itu, mahasiswa semakin aktif dan antusias dalam mengikuti seluruh rangkaian perkuliahan.

Dari hasil penelitian tentang pembelajaran bahasa bidang Sintaksis Bahasa Indonesia dengan metode brainstorming di atas. Dengan demikian dapat disimpulkan bahwa kemampuan mahasiswa dalam memahami frase, klausa, dan kalimat bahasa Indonesia mengalami peningkatan setelah mengikuti proses pembelajaran dengan metode brainstorming ini, dan perilaku mahasiswa mengalami perubahan lebih terbuka dan lebih antusias belajar tentang aspek 
kebahasaan, sekaligus menjadi lebih positif. Dalam pelaksanaan, mahasiswa memiliki kelincahan dalam mengemukakan pendapat tentang seluk-beluk sintaksis bahasa dengan materi yang ada dalam kehidupan di tengah masyarakat. Secara teoritis, mahasiswa sudah mengenal tentang seluk-beluk sintaksis dan produkproduk yang dihasilkan. Demikian juga dengan beranekaragaman sintaksis yang menyangkut pemakaian bahasa dalam kehidupan bermasyarakat.

Hasil observasi terlihat pertama mahasiswa selalu memperhatikan perkuliahan dari dosen pengampu mata kuliah, kedua yaitu antusias dan semangat dalam mengikuti perkuliahan, ketertarikan dengan metode brainstorming. Mahasiswa menjawab pertanyaan dosen dengan model curah gagasan. Mahasiswa bekerja sama dalam kelompoknya. Mahasiswa mempelajari materi dengan sungguh-sungguh dan menjawab soal uji kompetensi dan soal evaluasi dengan sungguh-sungguh. Angket tanggapan mahasiswa terhadap perkuliahan sintaksis diberikan pada 36 mahasiswa. Hasil angket tanggapan mahasiswa untuk perkuliahan menggunakan media dibanding dengan ceramah saja memberikan tanggapan dengan kategori sangat setuju (76\%) dan mahasiswa yang memberikan tanggapan dengan kategori setuju (34\%). Pelaksanaan perkuliahan menggunakan metode brainstorming, mahasiswa yang memberikan tanggapan dengan kategori sangat setuju (68\%), dan yang memberikan tanggapan dengan kategori setuju (32\%). Kualitas tampilan dalam metode brainstorming, memberikan tanggapan dengan kategori sangat setuju (62\%) dan memberikan tanggapan dengan kategori setuju (38\%).

Pada pengaruh penggunaan metode brainstorming, mahasiswa memberikan tanggapan dengan kategori sangat setuju (70\%), dan mahasiswa memberikan tanggapan dengan kategori baik atau setuju (30\%). Hasil angket ini tidak menemukan mahasiswa yang memberi tanggapan kurang baik maupun buruk. Evaluasi diberikan dengan bentuk tes, setelah dikoreksi, maka hasil belajar mahasiswa menunjukkan bahwa dari 36 sampel terbukti pada siklus pertama, nilai rata-rata mahasiswa 70 (tujuh puluh) dengan rincian 7 (tujuh) mahasiswa nilai baik sekali atau 19\%. Mahasiswa dengan nilai baik 19 (sembilan belas) atau 53\%. Kemudian, mahasiswa dengan nilai cukup 10 (sepuluh) atau 28\%. Selanjutnya pada siklus II hasil nilai mahasiswa rata-rata 78,5 (tuju puluh delapan koma lima). 
Hasil evaluasi menunjukkan 56\% mahasiswa mendapatkan nilai dengan kategori sangat baik dan $46 \%$ mahasiswa dalam kategori baik, dan tidak ada mahasiswa yang mendapat nilai pada kategori cukup, kurang maupun gagal.

\section{Simpulan}

Berdasarkan hasil penelitian dan pembahasan dapat disimpulkan bahwa: (1) hasil belajar sintaksisi dengan metode brainstorming ini diikuti dengan perubahan sikap dan perilaku mahasiswa yang lebih positif. Pada siklus I mahasiswa terlihat senang dan bersemangat dalam pembelajaran. Selain itu, mahasiswa semakin aktif dan antusias dalam mengikuti seluruh rangkaian pembelajaran. (2) Hasil perkuliahan sintaksis meningkat dengan hasil memuaskan. Terbukti pada siklus pertama, nilai rata-rata mahasiswa 70 (tujuh puluh) dengan rincian 7 (tujuh) mahasiswa nilai baik sekali atau $19 \%$. Mahasiswa dengan nilai baik 19 (sembilan belas) atau 53 \%. Kemudian, mahasiswa dengan nilai cukup berjumlah 10 (sepuluh) atau 28\%. Sedang pada siklus kedua pencapaian nilai rata-rata 78,5 (tujuh puluh delapan koma lima) dengan rincian 12 (dua belas) mahasiswa mendapat nilai baik sekali atau $33 \%$, sedangkan mahasiswa yang mendapatkan nilai baik sebanyak 24 (dua puluh empat) mahasiswa atau $67 \%$.

\section{Daftar Pustaka}

Amin, D. (2017). Penerapan Metode Curah Gagasan (Brainstorming) Untuk Meningkatkan Kemampuan Mengemukakan Pendapat Siswa. Jurnal Pendidikan Sejarah, 5(2), 1. doi:10.21009/jps.052.01

Depdikbud. (1999). Petunjuk Pelaksanaan Proses Belajar Mengajar. Jakarta: Balai. Pustaka.

Firdaus, A., Wahdah Humaira, H., \& Firdaus, A. (2019). Pengaruh Metode Brainstorming terhadap Menulis Persuasif Siswa Kelas VIII SMPN 15 Sukabumi. Basastra, 8(2), 142. doi:10.24114/bss.v8i2.14467

Indihadi, D. (2018). Pembelajaran Menulis Berbasis "Brainstorming." Indonesian Journal of Primary Education, 2(2), 91. doi:10.17509/ijpe.v2i2.15172 
Kemmis, S. \& Mc.Taggart, R. (1988). The Action Research Planner. Victoria: DeakinUniversity Press.

Noermanzah \& Friantary, H. (2019). Development of Competency-Based Poetry Learning Materials for Class X High Schools. International Journal of Recent Technology and Engineering, 8(4).

Noermanzah, N. (2015). Peran Dosen Bahasa dan Sastra Indonesia dalam Mempertahankan Bahasa Indonesia sebagai Alat Pemersatu Negara Kesatuan Republik Indonesia pada Era Globalisasi. Dalam Prosiding Seminar Nasional Bulan Bahasa 2015. Unit Penerbitan FKIP Universitas Bengkulu, p. 274. http://repository.unib.ac.id/11133/

Noermanzah, N. (2017). Struktur Kalimat Tunggal Bahasa Sindang di Kota Lubuklinggau dan Pengaruhnya dalam Pembelajaran Bahasa Indonesia. AKSIS: Jurnal Pendidikan Bahasa dan Sastra Indonesia, 1(1), 1-2. doi:10.21009/aksis.010101

Ramlan. (1987). IImu Bahasa Indonesia: Sintaksis. Yogyakarta: CV Karyono.

Rawlinson, J. G. (2017). What is brainstorming? Creative Thinking and Brainstorming, 35-54. doi:10.4324/9781315259000-2

Roestiyah, N. K. (2001). Strategi Belajar Mengajar. Jakarta: Rineka Cipta.

Sudaryanto. (2015). Peningkatan Penguasaan Konsep Sintaksis Bahasa Indonesia melalui Penerapan Media Peta Konsep pada Jurusan Pendidikan Bahasa dan Sastra Indonesia. LITERA, 6(1). doi:10.21831/Itr.v6i1.6814

Suyatno. (2009). Menjelajah Pembelajaran Inovatif. Sidoarjo: Masmedia Buana Pustaka.

Utami, D. (2015). Pengaruh Metode Brainstorming terhadap Kemampuan Berpikir Kritis pada Pembelajaran IPA. Jurnal Pendidikan Dasar, 6(2), 232. doi:10.21009/jpd.062.05 